FEDERAL RESERVE BANK OF SAN FRANCISCO

WORKING PAPER SERIES

\title{
Capital Controls and Optimal Chinese Monetary Policy
}

\author{
Chun Chang \\ Shanghai Advanced Institute of Finance, \\ Shanghai Jiao Tong University \\ Zheng Liu \\ Federal Reserve Bank of San Francisco \\ Mark M. Spiegel \\ Federal Reserve Bank of San Francisco
}

January 2015

Working Paper 2012-13

http://www.frbsf.org/publications/economics/papers/2012/wp12-13bk.pdf

The views in this paper are solely the responsibility of the authors and should not be interpreted as reflecting the views of the Federal Reserve Bank of San Francisco, the Federal Reserve Bank of St. Louis, or the Board of Governors of the Federal Reserve System. This paper was produced under the auspices of the Center for Pacific Basin Studies within the Economic Research Department of the Federal Reserve Bank of San Francisco. 


\title{
CAPITAL CONTROLS AND OPTIMAL CHINESE MONETARY POLICY
}

\author{
CHUN CHANG, ZHENG LIU, AND MARK M. SPIEGEL
}

\begin{abstract}
China's external policies, including capital controls, managed exchange rates, and sterilized interventions, constrain its monetary policy options for maintaining macroeconomic stability following external shocks. We study optimal monetary policy in a dynamic stochastic general equilibrium (DSGE) model that incorporates these "Chinese characteristics." The model highlights a monetary policy tradeoff between domestic price stability and costly sterilization. The same DSGE framework allows us to evaluate the welfare implications of alternative liberalization policies. Capital account and exchange rate liberalization would have allowed the Chinese central bank to better stabilize the external shocks experienced during the global financial crisis.
\end{abstract}

Date: January 22, 2015.

Key words and phrases. China, sterilization, capital controls, renminbi exchange rates, optimal policy.

JEL classification: E42, F31, F32.

Chang: Shanghai Advanced Institute of Finance (SAIF), Shanghai Jiao Tong University; Email: cchang@saif.sjtu.edu.cn. Liu: Federal Reserve Bank of San Francisco; Email: Zheng.Liu@sf.frb.org. Spiegel: Federal Reserve Bank of San Francisco; Email: Mark.Spiegel@sf.frb.org. We are grateful to an anonymous referee for helpful comments and constructive suggestions. We also thank Paul Bergin, Javier Bianchi, Mick Devereux, Charles Engel, Urban Jerrmann, Ding Jianping, David Li, Ying Li, Fernanda Nechio, Glenn Rudebusch, Rob Shimer, Carl Walsh, Jian Wang, Shangjin Wei, Jenny $\mathrm{Xu}$, and seminar participants at the City University of Hong Kong-Bank of Finland Institute Conference on the Renminbi, Claremont McKenna College, the Federal Reserve Bank of San Francisco Center for Pacific Basin Studies Research Conference, the Hong Kong Institute of Monetary Research Conference, the IMF, Shanghai University of Finance and Economics, the Shanghai Advanced Institute of Finance (SAIF), Tsinghua University, UC Davis, and the University of Wisconsin for helpful comments. The views expressed herein are those of the authors and do not necessarily reflect the views of the Federal Reserve Bank of San Francisco or the Federal Reserve System. 


\section{INTRODUCTION}

China maintains a number of restrictions on its external sector. Its capital account is effectively closed, with tight restrictions on the access of domestic citizens to participation in international asset markets. China also maintains controls over fluctuations in its exchange rates. These restrictions, combined with China's open trade stance and large and persistent current account surpluses pose challenges to the country's monetary policy. Under capital account restrictions, the People's Bank of China (PBOC, China's central bank) intervenes by purchasing foreign-currency revenues from exporters at prevailing exchange rates, with the purchases financed by either issuing domestic currency or domestic bonds. The portion of foreign asset purchases financed by selling domestic bonds is said to be "sterilized," in that it does not result in an expansion of money supply. Given this policy stance, PBOC holdings of foreign reserves have grown rapidly and China's monetary policy has become increasingly sensitive to global financial conditions (see Figure 1). ${ }^{1}$

To study the implications of China's capital account restrictions for its monetary policy, we construct a dynamic stochastic general equilibrium (DSGE) model. In addition to limited access of private agents to international asset markets, the model features a number of other "Chinese characteristics" that mirror that nation's current unique policy stance, including a nominal exchange rate peg and sterilized central bank interventions.

Unlike the standard DSGE model, portfolio allocations for both the private sector and the central bank are a key part of our model's transmission mechanism and influence monetary policy decisions. To allow for a role of portfolio decisions, the model introduces a wedge into the uncovered interest rate parity (UIP) condition. The model is otherwise similar to the standard DSGE model with sticky prices and optimizing private agents.

The model is used to study optimal monetary policy, under which the central bank maximizes the representative household's welfare. A main finding is that, under the prevailing capital account regime, optimal monetary policy in China involves a tradeoff between sterilization costs and price stability.

Our analysis highlights the impact of this tradeoff for optimal Chinese monetary policy during the 2008-2009 global financial crisis. During that crisis, China faced

\footnotetext{
${ }^{1}$ With rapidly growing foreign reserves, current account surpluses run by China may require increasingly intensive sterilization to maintain the government's exchange-rate goals [e.g., Glick and Hutchison (2009)].
} 
persistent declines in foreign interest rates as the Federal Reserve and central banks in other advanced economies reduced short-term interest rates close to the zero lower bound and adopted quantitative easing and other unconventional monetary policies. In addition, sharp spikes of uncertainty in financial markets caused investors to shift their portfolio allocations toward low-risk and high-liquidity assets - such as U.S. Treasuries - in a "flight to liquidity," pushing down yields on China's foreign reserves.

In contrast, nominal interest rates on China's domestic assets remained relatively high throughout the crisis period. Figure 2 shows that 3-month Treasury rates were typically higher than China's domestic interest rates (such as the Shanghai Interbank Offered Rate or SHIBOR) before the global financial crisis. Since the crisis, however, the interest rate spread has reversed sign, with the Treasury rate falling to close to zero while the SHIBOR remained elevated. Thus, prior to the crisis, the PBOC enjoyed fiscal benefits from sterilization activity because it entailed exchanging lowyield domestic debt for high-yield foreign assets. Since the crisis, however, sterilization has become costly to the $\mathrm{PBOC}$, as foreign interest rates declined sharply relative to domestic rates. ${ }^{2}$

Increases in the costs of sterilization create a tradeoff for the PBOC in implementing monetary policy to achieve price stability. The PBOC could mitigate the sterilization costs by reducing sterilization activity and increasing the share of foreign-asset purchases financed by money supply. However, this policy could raise inflation. In practice, China's money supply did increase substantially in the wake of the global financial crisis, with the M2 growth rate rising sharply from about 15\% in 2007 to over $25 \%$ in 2009. China's inflation surged from moderate levels to over $6 \%$ by 2012 (see Figure 3), despite rapid increases in the PBOC's required reserve ratio from $14 \%$ in late 2007 to $21 \%$ in 2011. This surge in inflation during a period when foreign interest rates dropped sharply relative to domestic rates demonstrates the tradeoff between sterilization costs and price stability faced by the PBOC.

\footnotetext{
${ }^{2}$ The Chinese situation is analogous to the experience of emerging market economies facing capital inflow surges. Sterilization was considered potentially costly due to interest rate premia on domestic debt [e.g., Calvo (1991)]. Existing studies suggest the fiscal costs of sterilization can be substantial, between 0.25 and 0.5 percent of GDP (e.g. Calvo et al. (1996) and Kletzer and Spiegel (1998)). However, these costs were calculated ex post in the absence of default. Ex ante, uncovered interest parity (UIP) should equalize expected returns on domestic and foreign assets net of risk premia. For that reason, these costs were referred to as "quasi-fiscal costs." In contrast, China's closed capital account allows deviations from UIP, so that observed deviations represent true expected costs of sterilization since default risk is minimal.
} 
The same DSGE framework allows us to examine the implications of potential policy liberalizations. We consider three liberalizations: Relaxing capital account restrictions to levels similar to those in other emerging market economies, letting the exchange rate float, and relaxing both restrictions. In the presence of shocks to foreign interest rates and export demand, relaxing capital controls leads to gains in macroeconomic stability, even when the exchange rate remains pegged. On the other hand, for a given capital account regime, a floating exchange rate helps restore external balances and enables the central bank to gain more flexibility in addressing domestic price stability. Finally, relaxing both capital account controls and exchange rate pegs provide the greatest macroeconomic stability gains.

The remainder of this paper is divided into five sections. Section II provides a brief review of the literature on optimal monetary policy in a DSGE framework. Section III introduces the benchmark DSGE model with capital controls, exchange rate pegs, and sterilized interventions by the central bank. Section IV examines optimal monetary policy under the benchmark model in the wake of negative shocks to foreign interest rates and export demand, similar to that which occurred during the global financial crisis. Section V examines optimal policy under the three alternative liberalizations and compares the effectiveness of optimal policy under each regime. Section VI provides some concluding remarks.

\section{Literature on Optimal Monetary Policy}

Our work adds to the literature on optimal monetary policy in a New Keynesian DSGE framework. In the standard DSGE model of a closed economy, monetary policy faces no tradeoff between stabilizing inflation and stabilizing the output gap (Blanchard and Galí, 2007). This "divine coincidence," which is obtained from a closed economy model, can be carried over to a small open economy with perfect international capital flows and flexible exchange rates (Clarida et al., 2002). Subsequent literature shows that the divine coincidence breaks down in more general environments, such as one with multiple sources of nominal rigidities. Examples include a model with sticky prices and sticky nominal wages (Erceg et al., 2000), a model with sticky prices in multiple sectors (Mankiw and Reis, 2003; Huang and Liu, 2005), and a model with multiple countries (Benigno, 2004; Liu and Pappa, 2008). Galí and Monacelli 
(2005) consider optimal monetary policy in a small open economy with staggered Calvo pricing. ${ }^{3}$

In our benchmark model with a closed capital account and a pegged exchange rate, monetary policy faces additional constraints in stabilizing inflation and output fluctuations. Since private agents in the economy are restricted from trading foreign assets and the nominal exchange rate is fixed, the country is effectively in financial autarky and international risk-sharing becomes infeasible. ${ }^{4}$ Because the nominal exchange rate is pegged, adjustments in the terms of trade (or the real exchange rate) cannot be used to mitigate the impact of external shocks. Under this regime, increases in the cost of sterilization following a sudden decline in foreign interest rates further constrain the central bank's ability to stabilize domestic price inflation. To our knowledge, this source of tradeoff for monetary policy (arising from capital controls and exchange-rate pegs) is new to the literature. ${ }^{5}$

The recent global financial crisis has generated a renewed interest in the implications of capital controls and exchange-rate pegs. Policy makers have become more amenable to capital controls under certain conditions [e.g., Ostry et al. (2010)], as it is unclear that financial integration reduces macroeconomic volatility. Prasad et al. (2005) have argued that, with a weak financial system, liberalizing the capital account would pose significant risks for China. Farhi and Werning (2012) argue that capital controls can mitigate the effects of excess international capital movements caused by risk premium shocks. Jeanne and Korinek (2010) demonstrate that a time-varying Pigouvian tax on external borrowing can undo the pecuniary externality associated with borrowing constraints.

However, recent empirical studies have found limits to the effectiveness of capital controls. Forbes et al. (2013) argues that while capital controls may mitigate financial fragility, they are less effective for meeting macroeconomic targets. De Paoli and Lipinska (2013) note that while capital controls may be welfare-enhancing from the point of view of an individual country, they may trigger adverse responses from other nations and end up reducing welfare. Their analysis therefore demonstrates the merits

\footnotetext{
${ }^{3}$ See Corsetti et al. (forthcoming) for a survey of the literature on optimal monetary policy in open economies.

${ }^{4}$ If the exchange rate was instead flexible, international risk sharing could still be achieved under financial autarky, as in Cole and Obstfeld (1991).

${ }^{5}$ There are very few studies that use a DSGE framework to evaluate alternative policies for the Chinese economy. Two exceptions include Miao and Peng (2011) and Chen et al. (2012), who present closed-economy DSGE models with financial frictions to study China's credit policy.
} 
of international policy coordination in the use of capital controls. Our paper focuses on the constraints that capital account restrictions and exchange-rate pegs impose on the ability of optimal monetary policy to achieve domestic price stability.

\section{BENCHMARK MODEL}

This section introduces a benchmark DSGE model with capital controls. Section III.1 highlights the key departures of the model from the standard DSGE model. Section III.2 provides some details of our model specification.

III.1. Key features of the model. Our model generalizes the standard DSGE framework to incorporate some key features of China's economy and policy regimes to study the implications of capital account restrictions and sterilization policy. For this purpose, however, a simple extension of the standard DSGE model such as that in Christiano et al. (2005) to an open economy is not sufficient. In those models, the uncovered interest rate parity (UIP) condition holds and portfolio allocations are inconsequential. Thus, sterilization has no direct fiscal consequences.

The UIP condition is clearly violated in China. Figure 2 shows that China's domestic interest rates have been much higher than foreign rates since the 2008-09 crisis, a period during which China has maintained tight controls over the exchange rate. Our model generates deviations from UIP because of imperfect substitutions between domestic and foreign assets. In particular, private agents need to pay a quadratic adjustment cost when they change their portfolio shares of foreign and domestic bond holdings. These can be interpreted as representing in part bureaucratic barriers erected by the government to restrict private agents' access to foreign assets. ${ }^{6}$

We also restrict the policy instruments available to the government (in our case, the central bank). Under capital controls, the central bank purchases foreign currency revenues from exporters at the prevailing exchange rate. If the purchases could be financed by lump-sum taxes collected from the private households, then sterilization would be inconsequential. To avoid that outcome, lump-sum taxes are assumed to be unavailable and reserve purchases need to be financed by either increasing the money supply or by issuing domestic bonds. As a consequence, the distinction between

\footnotetext{
${ }^{6}$ The portfolio adjustment costs serve as a flexible approach to capturing the observed deviations of UIP under capital controls in China. In reality, there are leakages in China's capital controls [e.g. Jeanne (2012)], leaving a complete ban on private holdings of foreign assets unrealistic. A similar UIP wedge can be obtained from financial frictions in the foreign exchange market (Gabaix and Maggiori, 2013).
} 
money-financed and bond-financed purchases of foreign reserves becomes an important equilibrium object that is central to sterilization policy.

Furthermore, to stay consistent with China's prevailing capital account regime, foreign investors are not allowed to hold Chinese bonds. Under China's capital account policy, both inflows and outflows of foreign portfolio investment are highly restricted. As a consequence, the shares of foreign portfolio assets and liabilities in China's GDP have been very small (about 3 or $4 \%$ in 2010) relative to other countries with high capital mobilities (with the shares averaging over 50\%) (Song et al., 2013).

III.2. Model details. Consider a global economy with two countries - the home country (China) and the rest of the world. The focus here is on describing the home country's problems. Explicit assumptions about the foreign country are made where necessary.

The home country is populated by a continuum of infinitely lived households. The representative household consumes a final good, holds real money balances, and supplies labor to firms. The final good is a composite of differentiated retail products, each of which is produced using labor and intermediate goods as inputs. Intermediate goods are a composite of domestic goods and imported materials. Final goods can be used for consumption, as an intermediate input for production, or exported to the foreign country. All markets are perfectly competitive, except that the markets for differentiated retail goods are monopolistically competitive. Each retailer takes all prices but its own as given and sets a price for its differentiated product.

The representative household faces a segmented asset market, where she has limited access to the foreign bond market. The household is allowed to choose a portfolio of holdings of domestic and foreign currency bonds subject to a quadratic portfolio adjustment cost. As discussed in Section III.1, this feature captures the restricted access of domestic households to foreign asset markets under China's capital control policy, while allowing for small "leakages" of foreign assets to be held by the private sector. Further, under the capital controls regime, foreign investors are not allowed to hold Chinese assets.

The central bank purchases foreign assets from the private sector at the prevailing (and fixed) exchange rate, and it finances the purchases with money creation or domestic bond issuance. Lump-sum taxes are unavailable.

Monetary policy is a constrained optimum, in the sense that the central bank maximizes social welfare taking as given the private optimizing conditions. 
III.3. The representative household. The representative household chooses consumption $C_{t}$, money balances $M_{t}$, labor hours $L_{t}$, and the holdings of a nominal domestic bond $B_{t}$ and a foreign bond $B_{p t}^{*}$ to maximize her lifetime expected utility function:

$$
W=\mathrm{E} \sum_{t=0}^{\infty} \beta^{t}\left\{\ln C_{t}+\Phi_{m} \ln \frac{M_{t}}{P_{t}}-\Phi_{l} \frac{L_{t}^{1+\eta}}{1+\eta}\right\},
$$

subject to the sequence of budget constraints

$$
\begin{gathered}
C_{t}+\frac{M_{t}}{P_{t}}+\frac{B_{t}+e_{t} B_{p t}^{*}}{P_{t}}\left[1+\frac{\Omega_{b}}{2}\left(\frac{B_{t}}{B_{t}+e_{t} B_{p t}^{*}}-\bar{\psi}\right)^{2}\right] \leq \\
w_{t} L_{t}+\frac{M_{t-1}}{P_{t}}+\frac{R_{t-1} B_{t-1}+e_{t} R_{t-1}^{*} B_{p, t-1}^{*}}{P_{t}}+\frac{D_{t}}{P_{t}} .
\end{gathered}
$$

In these expressions, $P_{t}$ denotes the domestic price level, $e_{t}$ denotes the nominal exchange rate; $w_{t}$ denotes the real wage rate; $R_{t}$ and $R_{t}^{*}$ denote the nominal interest rates for domestic and foreign bonds, respectively; and $D_{t}$ denotes the nominal dividends received by the household from her ownership of retail firms. The term $\mathrm{E}$ is an expectations operator. The parameter $\beta \in(0,1)$ is a subjective discount factor, $\Phi_{m}>0$ is the utility weight for real money balances, $\Phi_{l}>0$ is the utility weight for leisure, and $\eta>0$ is the inverse Frisch elasticity of hours worked. The parameter $\Omega_{b}$ measures the size of portfolio adjustment costs. The parameter $\bar{\psi}$ denotes the steady-state portfolio share of domestic bonds in the total value of private bond holdings.

Denote by $\Lambda_{t}$ the Lagrangian multiplier for the budget constraint (2) and by $m_{t} \equiv$ $\frac{M_{t}}{P_{t}}$ the quantity of real money balances. The optimal money demand equation is given by

$$
\frac{\Phi_{m}}{\Lambda_{t} m_{t}}=1-\mathrm{E}_{t} \frac{\beta \Lambda_{t+1}}{\Lambda_{t}} \frac{1}{\pi_{t+1}} .
$$

The optimizing labor supply decision implies that

$$
w_{t}=\frac{\Phi_{l} L_{t}^{\eta}}{\Lambda_{t}}
$$

Denote by $\psi_{t}=\frac{B_{t}}{B_{t}+e_{t} B_{p t}^{*}}$ the portfolio share of domestic bonds in total bond holdings. The optimal choices of $B_{t}$ and $B_{p t}^{*}$ imply that

$$
\Omega_{b}\left(\psi_{t}-\bar{\psi}\right)=\mathrm{E}_{t} \frac{\beta \Lambda_{t+1}}{\Lambda_{t}} \frac{1}{\pi_{t+1}}\left[R_{t}-R_{t}^{*} \frac{e_{t+1}}{e_{t}}\right],
$$

where $\pi_{t+1} \equiv \frac{P_{t+1}}{P_{t}}$ denotes the inflation rate from period $t$ to $t+1$. This equation represents a generalized UIP condition. Absent portfolio adjustment costs (i.e., $\Omega_{b}=$ 
$0)$, this equation reduces to

$$
0=\mathrm{E}_{t} \frac{\beta \Lambda_{t+1}}{\Lambda_{t}} \frac{1}{\pi_{t+1}}\left[R_{t}-R_{t}^{*} \frac{e_{t+1}}{e_{t}}\right]
$$

which corresponds to the standard UIP condition that links relative interest rates to the expected depreciation of the domestic currency. With portfolio adjustment costs, however, domestic and foreign bonds are imperfect substitutes. Accordingly, the UIP condition needs to be modified to include a new term that depends on the portfolio share of domestic bonds, $\psi_{t}$. As revealed by equation (5), the portfolio share of domestic bonds depends positively on the spread between the domestic interest rate and the exchange-rate adjusted foreign interest rate. Thus, this equation represents a downward-sloping demand curve for domestic bonds: when the relative price of domestic bonds falls (i.e., when the relative nominal interest rate increases), the household's optimal share of domestic bond holdings increases a finite amount.

III.4. The retail goods sector. There is a continuum of retailers, each producing a differentiated product $Y_{t}(j)$ using the constant returns technology

$$
Y_{t}(j)=\Gamma_{t}(j)^{\phi}\left(Z_{t} L_{t}(j)\right)^{1-\phi}
$$

where $Z_{t}$ is a labor-augmenting technology, $\Gamma_{t}(j)$ denotes the input of intermediate goods, and $L_{t}(j)$ denotes the input of labor. The parameter $\phi \in[0,1]$ is the cost share of the intermediate input. Technology is assumed to grow at a rate of $\lambda_{z t} \equiv \frac{Z_{t}}{Z_{t-1}}$.

Denote by $v_{t}$ the real marginal cost for firms. Cost-minimizing implies that

$$
v_{t}=\tilde{\phi} q_{m t}^{\phi}\left(\frac{w_{t}}{Z_{t}}\right)^{1-\phi}
$$

where $q_{m t}$ denotes the relative price of intermediate goods and $\tilde{\phi} \equiv \phi^{-\phi}(1-\phi)^{\phi-1}$ is a constant. The conditional factor demand derived from the cost-minimization problem implies

$$
\frac{w_{t}}{q_{m t}}=\frac{1-\phi}{\phi} \frac{\Gamma_{t}(j)}{L_{t}(j)} .
$$

Given that input factors are perfectly mobile across all retail firms, the wage rate and the relative price of intermediate goods are identical for each firm, as is the real marginal cost.

Retailers face competitive input markets and a monopolistically competitive product market. Retailer $j$ takes as given the input prices $q_{t}$ and $w_{t}$, the price level $P_{t}$, and the demand schedule for its product, and chooses a price $P_{t}(j)$ for its own differentiated product to maximize expected discounted dividend flows. Price adjustments 
are costly. Following Rotemberg (1982), retailers face a quadratic price adjustment cost

$$
\frac{\Omega_{p}}{2}\left(\frac{P_{t}(j)}{\pi P_{t-1}(j)}-1\right)^{2} C_{t}
$$

where $\Omega_{p}$ measures the size of price adjustment costs and $\pi$ is the steady-state inflation rate. ${ }^{7}$ In particular, the retailer solves the problem

$$
\operatorname{Max}_{P_{t}(j)} \quad E_{t} \sum_{k=0}^{\infty} \beta^{k} \frac{\Lambda_{t+k}}{\Lambda_{t}}\left[\left(\frac{P_{t+k}(j)}{P_{t+k}}-v_{t+k}\right) Y_{t+k}^{d}(j)-\frac{\Omega}{2}\left(\frac{P_{t+k}(j)}{\pi P_{t+k-1}(j)}-1\right)^{2} C_{t+k}\right],
$$

where $Y_{t}^{d}(j)$ is the demand schedule given by

$$
Y_{t}^{d}(j)=\left[\frac{P_{t}(j)}{P_{t}}\right]^{-\theta_{p}} Y_{t}
$$

and the price level is related to individual prices through $P_{t}=\left[\int_{0}^{1} P_{t}(j)^{1-\theta_{p}} d j\right]^{\frac{1}{1-\theta_{p}}}$, with $\theta_{p}>1$ denoting the elasticity of substitution between differentiated retail products.

In a symmetric equilibrium with $P_{t}(j)=P_{t}$ for all $j$, the optimal pricing decision implies that

$$
v_{t}=\frac{\theta_{p}-1}{\theta_{p}}+\frac{\Omega_{p}}{\theta_{p}} \frac{C_{t}}{Y_{t}}\left[\left(\frac{\pi_{t}}{\pi}-1\right) \frac{\pi_{t}}{\pi}-\beta \mathrm{E}_{t}\left(\frac{\pi_{t+1}}{\pi}-1\right) \frac{\pi_{t+1}}{\pi}\right]
$$

which is the Phillips curve relation. Absent price adjustment costs (i.e., when $\Omega_{p}=0$ ), the optimal pricing rule would imply that the real marginal cost $v_{t}$ equals the inverse markup.

III.5. The intermediate goods sector. Intermediate goods are produced using both domestically produced final goods and imported goods, with the production function given by

$$
\Gamma_{t}=\Gamma_{h t}^{\alpha} \Gamma_{f t}^{1-\alpha},
$$

where $\Gamma_{h t}$ and $\Gamma_{f t}$ denote the quantities of domestically produced and imported goods, respectively, and $\alpha \in(0,1)$ is the expenditure share of domestic input.

Cost-minimizing implies that the relative price of intermediate goods is given by

$$
q_{m t}=\tilde{\alpha} q_{t}^{1-\alpha}
$$

\footnotetext{
${ }^{7}$ For convenience, adjustment costs are normalized in units of aggregate consumption. The main results go through if the adjustment costs are in units of aggregate output.
} 
where $q_{t} \equiv \frac{e_{t} P_{t}^{*}}{P_{t}}$ is the real exchange rate and $P_{t}^{*}$ denotes the foreign price level. This relation suggests that the cost of intermediate goods is a monotonic function of the real exchange rate or the terms of trade. Cost-minimizing also implies that

$$
q_{t}=\frac{1-\alpha}{\alpha} \frac{\Gamma_{h t}}{\Gamma_{f t}}
$$

III.6. The external sector and current account. The home country imports materials and exports final goods. The current account balance equals the sum of trade surplus and net interest income received from holdings of foreign assets. Specifically, the current account is given by

$$
c a_{t}=X_{t}-q_{t} \Gamma_{f t}+\frac{e_{t}\left(R_{t-1}^{*}-1\right) B_{t-1}^{*}}{P_{t}}
$$

where $X_{t}$ represents the quantity of exports and $B_{t-1}^{*}$ denotes the country's aggregate holdings of foreign-currency bonds at the beginning of period $t$.

In each period, a current-account surplus (deficit) implies increases (decreases) in the country's holdings of foreign bonds. The aggregate stock of foreign bonds (denoted by $B_{t}^{*}$ ) thus evolves according to the law of motion

$$
c a_{t}=e_{t} \frac{B_{t}^{*}-B_{t-1}^{*}}{P_{t}} .
$$

The foreign interest rate $R_{t}^{*}$ is exogenous and follows the stationary stochastic process

$$
\ln R_{t}^{*}=\left(1-\rho_{r}\right) \ln R^{*}+\rho_{r} \ln R_{t-1}^{*}+\sigma_{r} \varepsilon_{r t},
$$

where $\rho_{r} \in(0,1)$ is a persistence parameter, $\sigma_{r}$ is the standard deviation of the shock, and $\varepsilon_{r t}$ is an i.i.d. standard normal process.

Foreign demand for the home country's exported goods is inversely related to the relative price of home goods and positively related to aggregate demand in the foreign country. The export demand schedule is given by

$$
X_{t}=\left(\frac{P_{t}}{e_{t} P_{t}^{*}}\right)^{-\theta} \tilde{X}_{t}^{*} Z_{t}=q_{t}^{\theta} \tilde{X}_{t}^{*} Z_{t},
$$

where, to obtain balanced growth, export demand is augmented by the level of domestic productivity. The term $\tilde{X}_{t}^{*}$ is an export demand shock and follows the stochastic process

$$
\ln \tilde{X}_{t}^{*}=\left(1-\rho_{x}\right) \ln \tilde{X}^{*}+\rho_{x} \ln \tilde{X}_{t-1}^{*}+\sigma_{x} \varepsilon_{x t},
$$

where $\rho_{x} \in(0,1)$ is a persistence parameter, $\sigma_{x}$ is the standard deviation, and $\varepsilon_{x t}$ is an i.i.d. standard normal process. 
III.7. Central bank flow-of-funds constraints and sterilization policy. The central bank issues domestic-currency bonds and domestic currency, and holds foreigncurrency reserves. In the benchmark model, the central bank allows the nominal exchange rate to appreciate at a constant rate (so that $\frac{e_{t}}{e_{t-1}}=\gamma_{e}$ ) and maintains capital account restrictions.

Under capital account restrictions, the central bank purchases foreign assets from private exporters. The purchases can be financed either by money creation or by domestic bond issuance. The central bank faces the flow-of-funds constraint

$$
e_{t}\left(B_{g t}^{*}-R_{t-1}^{*} B_{g, t-1}^{*}\right) \leq B_{t}^{s}-R_{t-1} B_{t-1}^{s}+M_{t}^{s}-M_{t-1}^{s},
$$

where $B_{g t}^{*}$ denotes the central bank's holdings of the foreign bond. ${ }^{8}$ The term $B_{t}^{s}$ denotes the domestic bond issued by the central bank, which is held entirely by domestic households. The central bank conducts sterilization policy by varying the share of foreign-asset purchases financed by money creation.

III.8. Market clearing and equilibrium. Given the central bank policy, an equilibrium in this economy is a sequence of prices $\left\{P_{t}, w_{t}, R_{t}, e_{t}, q_{t}, q_{m t}\right\}$ and aggregate quantities $\left\{C_{t}, Y_{t}, \Gamma_{t}, \Gamma_{h t}, \Gamma_{f t}, X_{t}, L_{t}\right.$,

$\left.M_{t}, M_{t}^{s}, B_{t}, B_{p t}^{*}, B_{g t}^{*}, B_{t}^{*}\right\}$, as well as the prices $P_{t}(j)$ and quantities $\left\{Y_{t}(j), L_{t}(j), \Gamma_{t}(j)\right\}$ for each retail firm $j \in[0,1]$, such that (i) taking all prices as given, the allocations solve the household's utility maximizing problem; (ii) taking all prices but its own as given, the price and allocations for each retail firm solves its profit maximizing problem, and (iii) markets for the final goods, labor, intermediate goods, money balances, and bond holdings all clear.

The market-clearing conditions are summarized below.

$$
\begin{aligned}
Y_{t} & =C_{t}+\Gamma_{h t}+X_{t}+\frac{\Omega_{p}}{2}\left(\frac{\pi_{t}}{\pi}-1\right)^{2} C_{t}+\frac{B_{t}+e_{t} B_{p t}^{*}}{P_{t}} \frac{\Omega_{b}}{2}\left(\psi_{t}-\bar{\psi}\right)^{2}, \\
L_{t} & =\int_{0}^{1} L_{t}(j) d j \\
\Gamma_{t} & =\int_{0}^{1} \Gamma_{t}(j) d j . \\
M_{t} & =M_{t}^{s}
\end{aligned}
$$

\footnotetext{
${ }^{8}$ To concentrate on monetary policy issues, other fiscal policies are taken as given. This includes implicit taxes that may be levied by the central bank, such as reserve requirements and the practice of handing over the central bank budget surplus to the general Treasury. Proper analysis of these fiscal policies would require a fuller model of both fiscal policies and the banking sector, which is an important subject for future research.
} 


$$
\begin{aligned}
B_{t}^{s} & =B_{t}, \\
B_{t}^{*} & =B_{p t}^{*}+B_{g t}^{*} .
\end{aligned}
$$

Equations (22)-(27) correspond, respectively, to the market clearing conditions for final goods, labor, intermediate-goods, money, domestic bonds, and foreign bonds.

Define real GDP as the sum of consumption and net exports, which is given by

$$
G D P_{t}=C_{t}+X_{t}-q_{t} \Gamma_{f t}
$$

Note that the definition of real GDP in (28) uses the expenditure approach. One may also use the income approach. Adding up the household's budget constraint (2) and the government's flow-of-funds constraint (21) and imposing the market clearing conditions yields

$$
G D P_{t} \equiv C_{t}+X_{t}-q_{t} \Gamma_{f t}=w_{t} L_{t}+\frac{D_{t}}{P_{t}}-\frac{B_{t}+e_{t} B_{p t}^{*}}{P_{t}} \frac{\Omega_{b}}{2}\left(\psi_{t}-\bar{\psi}\right)^{2},
$$

which equates real GDP to total domestic factor income -including wage income and profit income - net of portfolio adjustment costs, where profit income is net of price adjustment costs.

\section{Optimal monetary POLiCy}

The central bank solves a Ramsey problem to maximize the representative household's welfare $W$ defined in equation (1), taking as given the private sector's optimizing conditions. ${ }^{9}$

IV.1. Parameter calibration. There are four sets of parameters to be calibrated. These include the parameters in the utility function, those in the production function, those that characterize real and nominal rigidities, and those that are related to international trade. Table 1 summarizes the calibrated parameter values.

For the utility function parameters, the subjective discount factor is set to $\beta=$ 0.995. The money demand regression by Chari et al. (2000) implies that $\Phi_{m}=0.06$. We set $\eta=2$, implying a Frisch elasticity of labor supply of 0.5 , consistent with

\footnotetext{
${ }^{9}$ We solve the Ramsey problem using Dynare, with the planner's objective given by the representative household's utility function. The current version (4.4.2) of Dynare solves the Ramsey problem only up to first-order approximations. Given the complexity of our framework, it is infeasible to derive analytical second-order approximations to the planner's welfare objective following the approach in Woodford (2003). Still, as the stability rankings across regimes are unambiguous under our calibration, the relative stability performances under these regimes should be consistent with their relative welfare performances.
} 
microeconomic evidence (Pencavel, 1986). $\Phi_{l}$ is calibrated so that the steady-state fraction of labor hours is $40 \%$ of total time endowment.

For the technology parameters, the cost share of intermediate goods is set to $\phi=0.5$, consistent with the estimates of intermediate input share in U.S. data (Basu, 1995). Mean technology growth is set to $\bar{\lambda}_{z}=1.02$, so that real per capita GDP grows at an annual rate of 8 percent on average, similar to China's experience over the last two decades.

For the nominal rigidity parameters, the elasticity of substitution parameter $\theta_{p}$ is set to 10 , implying a steady-state price markup of about 11 percent, which is consistent with the estimate reported by Basu and Fernald (1997). The price adjustment cost parameter $\Omega_{p}$ is set to 60 , so that the model implies an average duration of price contracts of about four quarters. ${ }^{10}$

For the parameters in the external sector, the share of domestic intermediate input $\alpha$ is set to 0.7556 , so that the import-to-GDP ratio is 20 percent in the steady state, which corresponds to the average import-to-GDP ratio in China between 1990 and 2009. The export demand elasticity $\theta$ is set to 1.5 , which lies in the range of empirical estimates obtained by (Feenstra et al., 2012).

To calibrate the parameters in the portfolio adjustment cost functions and the steady-state share of foreign bonds held by the private sector, we log-linearize the modified UIP condition (5) and obtain

$$
\hat{R}_{t}-\hat{R}_{t}^{*}=\mathrm{E}_{t} \hat{\gamma}_{e, t+1}+\Omega_{b} \bar{\psi} \hat{\psi}_{t}
$$

where $\hat{\gamma}_{e, t+1}$ denotes deviations of nominal exchange rate growth $\left(\gamma_{e, t+1}=\frac{e_{t+1}}{e_{t}}\right)$ from the steady state and $\hat{\psi}_{t}$ denotes deviations of the portfolio share of domestic bonds from the steady-state. This equation reveals that an increase in the interest rate differential $\hat{R}_{t}-\hat{R}_{t}^{*}$, holding expected exchange rate movements constant, raises the private demand for domestic bonds relative to that for foreign bonds.

\footnotetext{
${ }^{10} \mathrm{Log}$-linearizing the optimal pricing decision equation (12) around steady state leads to a linear form of Phillips curve relation, with the slope of the Phillips curve given by $\kappa_{p} \equiv \frac{\theta_{p}-1}{\Omega_{p}} \frac{C}{Y}$. Our calibration implies a steady-state ratio of consumption to gross output of about 53 percent (not to be confused with official estimates of China's consumption-to-GDP ratio). The values of $\theta_{p}=10$ and $\Omega_{p}=60$ imply that $\kappa_{p}=0.08$. In an economy with Calvo (1983) price contracts, the slope of the Phillips curve is given by $\frac{\left(1-\beta \alpha_{p}\right)\left(1-\alpha_{p}\right)}{\alpha_{p}}$, where $\alpha_{p}$ is the probability that a firm cannot reoptimize prices. To obtain a slope of 0.08 for the Phillips curve in the Calvo model, $\alpha_{p}$ must be set equal to 0.75 (taking $\beta=0.995$ as given), which corresponds to an average duration of price contracts of $\frac{1}{1-\alpha_{p}}=4$ quarters.
} 
China has not been observed with an open capital account. We therefore calibrate $\bar{\psi}$ and $\Omega_{b}$ using evidence from other emerging market economies. The steady-state share of domestic bonds is set to $\bar{\psi}=0.9$, which lies in the range of estimates in the literature. For example, Coeurdacier and Rey (2011) found that average bond home bias worldwide in 2008 was equal to 0.75, while Aviat and Coeurdacier (2007) reported values for equity home bias around 0.80 . The empirical literature suggests that home bias figures for emerging Asia are even higher than those for the rest of the world, around 0.97. $\bar{\psi}=0.9$ therefore appears to be a reasonable value for China.

The parameter $\Omega_{b}$ is calibrated to capture average deviations from the UIP conditions. Specifically, a simple empirical model is estimated based on the modified UIP condition (5) using panel data from emerging market economies. The empirical model is given by

$$
\log \frac{e_{i t}}{e_{i, t-1}}-\left(R_{i, t-1}-R_{t-1}^{*}\right)=a_{i}-b \log \left(\psi_{i, t-1}\right)
$$

where $e_{i t}$ is the nominal exchange rate for country $i$ relative to the U.S. dollar (units of local currency per U.S. dollar) at the end of year $t, R_{i, t-1}-R_{t-1}^{*}$ is the difference between country $i$ 's nominal interest rate and the U.S. three-month T-bill rate at the end of year $t-1$, and $\psi_{i, t-1}$ is the share of domestic bonds held by country $i$ residents relative to the country's total bond holdings (including domestic and foreign bonds) at the end of year $t-1$.

Our sample is a balanced panel of 22 emerging market economies (not including China) with a sample period from 2001 to 2011. For the period up to 2008, portfolio share data comes from Coeurdacier and Rey (2011). We extend their sample through 2011 by merging data from the International Financial Statistics (IFS) and from the Bank for International Settlements (BIS). The point estimate of $b$ in equation (31) is about $0.2 .^{11}$ Given our calibration that $\bar{\psi}=0.9$, the value of $b=0.2$ implies that $\Omega_{b}=0.22$. This value of $\Omega_{b}=0.22$ is used to simulate optimal policy in the counterfactual case where China's capital account is partially liberalized (in which case China's capital account policy resembles those in other emerging market economies). Under the benchmark regime, China is assumed to have tighter capital controls than other emerging market economies. Thus, $\Omega_{b}$ is set at a greater value of 0.6 to capture

\footnotetext{
${ }^{11}$ In keeping with poor empirical performances of UIP-related conditions in the literature, this coefficient was marginally significant at the 15 percent level. However, Carneiro and $\mathrm{Wu}$ (2010) provide evidence that UIP-based exchange rate conditions hold at statistically significant levels for samples of emerging market economies.
} 
the fact that it is more costly for China's private households to adjust their bond portfolios. $^{12}$

For the shock parameters, $\rho_{r}$ is set to 0.98 to capture the persistent decline in foreign interest rates during and after the global financial crisis. In response to the crisis, the Federal Reserve lowered its interest rate target to near-zero levels in early 2009 and later signaled its intention to maintain the extremely low levels of the target for a long period of time. $\rho_{x}$ is set to 0.95 to capture the persistence in the global recession and the consequent declines in world demand. The standard deviations of each of the shocks are set to one percent.

IV.2. Dynamic responses to external shocks under optimal policy. We now examine the dynamic responses of macroeconomic variables under optimal monetary policy in our benchmark model with capital controls, nominal exchange rate pegs, and sterilized interventions. Our focus is on the effects of negative shocks to the foreign interest rate and export demand, similar to those observed following the 2008-2009 global financial crisis.

First, consider the effects of a persistent negative shock to the foreign interest rate. Figure 4 displays the impulse responses of a few macroeconomic variables. Capital account restrictions lead to short-run deviations from the UIP condition. Thus, despite the fixed exchange rate regime, the domestic interest rate declines only gradually and it does not instantaneously converge to the lower foreign interest rate. The increase in the interest-rate spread raises the costs of sterilization. Under optimal policy, the central bank chooses to sterilize less and to rely more on expanding the money supply to finance its foreign asset purchases. This expansionary monetary policy, along with the decline in the domestic nominal interest rate, boosts aggregate demand and, holding all else equal, raises real GDP and domestic inflation.

An increase in domestic inflation implies a real exchange rate appreciation because the nominal exchange rate is fixed. The appreciation then reduces export demand. Furthermore, the decline in the foreign interest rate directly reduces earnings from holdings of foreign assets. Both the real exchange-rate appreciation and the reductions in earnings on foreign assets contribute to a decline in current account balances relative to the steady state. This partially offsets the expansionary effects of monetary policy on aggregate demand. However, under our parameter calibration, the expansionary effects of monetary policy dominate the negative effects of declines in foreign earnings

\footnotetext{
${ }^{12}$ Experimentation with a reasonable range of values of $\Omega_{b}$ (with a lower bound of 0.22 ) suggests that the qualitative results are robust.
} 
and real exchange rate appreciation, producing a short-run increase in both inflation and real GDP.

Next, consider the effects of a negative shock to export demand. Figure 5 shows the impulse responses of the macroeconomic variables to that shock. A reduction in export demand reduces current account balances and the central bank's accumulation of foreign reserves. The central bank responds by reducing the intensity of sterilization and the supply of money. Lower export demand also implies lower aggregate demand which reduces real GDP and inflation. With a fixed nominal exchange rate regime, a decline in inflation implies a real depreciation, which helps alleviates the declines in export demand. Under optimal policy, the central bank keeps its nominal interest rate essentially unchanged. Thus, as aggregate demand falls, the demand for real money balances also fall; but since inflation declines, the fall in real money balances implies a fall in the money supply as well.

Figures 4 and 5 show that a negative export demand shock and a negative foreign interest rate shock move the macroeconomic variables in different directions, except that both shocks lower current account balances. In the aftermath of the global financial crisis, China experienced declines in global demand and increases in its domestic interest rate spread, consistent with these two shocks. The observed increases in inflation in China during that period suggest that concerns about sterilization costs influenced the actual conduct of Chinese monetary policy in a manner consistent with the tradeoff between sterilization costs and domestic price stability highlighted by our DSGE model.

\section{POLICY REFORMS}

In our benchmark model, the prevailing trade policy regime in China is taken as given, including capital account restrictions and exchange rate pegs. This regime imposes constraints on optimal monetary policy for China. In particular, a decline in foreign interest rates relative to China's domestic interest rates leads to an increase in the cost of sterilization and therefore an easing of domestic monetary policy, resulting in a short-run increase in inflation.

Recent Chinese policy discussions have considered liberalizing capital account restrictions and relaxing exchange rate pegs. We therefore examine - within the same DSGE framework - the macroeconomic implications of several counterfactual liberalizations. Three alternative policy reforms are considered: (i) relaxing capital account restrictions to levels similar to those in other emerging market economies, (ii) allowing 
the exchange rate to float, and (iii) relaxing restrictions on both the capital account and the exchange rate. Under each policy regime, the central bank solves the optimal monetary policy problem by maximizing the representative household's welfare, taking as given the private sector's optimizing decisions. As in the benchmark case, our focus continues to be on shocks to the foreign interest rate and export demand.

Welfare gains under each liberalization policy are measured by consumption equivalence relative to the benchmark policy regime. To be specific, we first compute the welfare under the benchmark policy regime (denoted by $V^{b}$ ) and under an alternative regime (denoted by $V^{a}$ ) upon obtaining the Ramsey allocations. Welfare gains are then calculated as the percentage decrease in consumption in perpetuity under the alternative regime such that the representative agent is indifferent between living under that regime and under the benchmark regime. In terms of the model variables, the welfare gains are measured by $\Delta$ such that

$$
\mathrm{E} \sum_{t=0}^{\infty} \beta^{t}\left[\log \left(C_{t}^{a}(1-\Delta)\right)+\Phi_{m} \log \left(m_{t}^{a}\right)-\Phi_{l} \frac{\left(L_{t}^{a}\right)^{1+\eta}}{1+\eta}\right]=V^{b}
$$

where the variables with a superscript $a$ denotes allocations under the alternative regime. With log-utility in consumption, the explicit expression for welfare gains satisfies

$$
\log (1-\Delta)=\frac{1}{1-\beta}\left(V^{b}-V^{a}\right)
$$

The macroeconomic stability properties of each policy regime can be compared by computing the unconditional volatilities of real GDP (denoted by $\sigma_{y}$ ), inflation $\left(\sigma_{\pi}\right)$, employment $\left(\sigma_{L}\right)$, the real exchange rate $\left(\sigma_{q}\right)$, and the current account $\sigma_{c a}$ in the simulated model driven by both types of external shocks. Table 2 displays the standard deviations of several macroeconomic variables and welfare under the benchmark policy regime and under each alternative liberalization policy.

Consider first a partial liberalization of capital controls, whereby China reduces it capital account restrictions to levels similar to other emerging market economies. In particular, the portfolio adjustment cost parameter $\left(\Omega_{b}\right)$ is lowered from 0.6 in the benchmark economy to 0.22 , the value estimated using data from other emerging market economies. Foreign investors continue to not be allowed to hold Chinese assets and the nominal exchange rate continues to be pegged.

Table 2 (the column under "Open capital account") shows that easing capital account controls leads to modest gains in macroeconomic stability relative to the benchmark regime. In particular, when capital account controls are eased, the volatilities in real GDP, inflation, and employment are slightly reduced, and the real exchange rate 
and current account are also better stabilized when the country is buffeted by shocks to the foreign interest rate and export demand. By liberalizing capital account restrictions, the central bank faces less pressure to absorb foreign capital inflows and thus has less need for sterilization. This reform reduces the tension between sterilization costs and domestic price stability, leading to superior outcomes for macroeconomic stability and welfare than those obtained under the benchmark regime. ${ }^{13}$

Consider next the outcome of optimal monetary policy when pegs on the nominal exchange rate are removed. In this counterfactual experiment, capital account restrictions are assumed to remain in place. When the nominal exchange rate is allowed to float, the central bank gains additional flexibility in conducting domestic monetary policy. To close the model requires specifying an instrument for domestic monetary policy (i.e., a nominal anchor). Following the original work by Taylor (1993), the central bank follows the interest rate rule

$$
\hat{R}_{t}=1.5 \hat{\pi}_{t}+0.5 G \hat{D} P_{t},
$$

where the variables $\hat{R}_{t}, \hat{\pi}_{t}$, and $G \hat{D} P_{t}$ denote the log-deviations of, respectively, the nominal interest rate, the inflation rate, and real GDP from steady state.

Table 2 (the column under "Flexible exchange rate") shows that allowing the exchange rate to float can achieve better macroeconomic stability and higher welfare than the benchmark regime, even though capital controls remain in place. With a floating exchange rate, the central bank gains more flexibility in maintaining external balances through exchange-rate adjustments in face of external shocks.

Finally, consider the implications of relaxing restrictions on both the capital account and the nominal exchange rate (i.e., a combination of the first two liberalization polices). This policy reform leads to further gains in macroeconomic stability relative to each of the two alternative liberalization policies alone. However, relative to the floating exchange rate regime, the additional gains from also relaxing capital account restrictions appear to be small. ${ }^{14}$

\footnotetext{
${ }^{13}$ Since other distortions remain (e.g., sticky prices and fixed exchange rates) when capital account restrictions are alleviated in our counterfactual experiment, the analysis here is necessarily about second-best policies. Under calibrated parameters, modest gains in macroeconomic stability are obtained. In general, however, in the presence of other shocks or other frictions not studied in our model, the second-best policy outcome may be different.

${ }^{14}$ These results, again, reflect second-best policy outcomes and depend on the parameter calibration and sources of shocks. Moreover, they also depend on assumptions about the utility function. For example, Bianchi (2011) shows in a small open economy model that an exchange rate peg leads to higher welfare if intra- and inter-temporal elasticities of substitution in preferences are sufficiently
} 


\section{CONCLUSiOn}

China's prevailing policy regime features capital controls, exchange rate targets, and sterilized interventions. Under these restrictions, optimal Chinese monetary policy involves a tradeoff between sterilization costs and domestic price stability. This tradeoff is illustrated in a DSGE model calibrated to Chinese and global data. The model reveals that, following a negative shock to foreign interest rates similar to that which occurred during the global financial crisis, optimal policy calls for a reduction in sterilization activity, resulting in monetary policy easing and an increase in inflation.

The same DSGE framework allows us to examine the implications of several alternative liberalization policies for macroeconomic stability and social welfare. These liberalization policies include: (i) partially easing capital controls, (ii) letting the exchange rate float, and (iii) doing both simultaneously. Under calibrated parameters, the regime that combines a partially liberalized capital account and a floating exchange rate performs best, although liberalizing either capital controls or exchange rate targets leads to gains in macroeconomic stability and welfare.

Easing capital account restrictions mitigates central bank concerns about sterilization costs and allows it to choose policies that achieve better stability. On the other hand, by allowing the exchange rate to float, the central bank can respond to external shocks by adjusting the exchange rate; which helps reduce external imbalances and shields the country from the adverse impact of fluctuations in foreign conditions, even when the capital account remains closed. Consequently, while our model is quite stylized and the relative numerical rankings should not be pushed too aggressively, our findings suggest that even partial reform of China's existing trade policy regime-either through opening the capital account or by letting exchange rate float - can help improve the Chinese central bank's ability to weather external shocks and achieve better macroeconomic stability.

In reality, China faces many additional distortions. Liberalization of these other distortions would in general also have second-best consequences. A coherent theoretical framework similar to that derived in this paper would therefore likely be useful in assessing the desirable priorities of other policy reforms as well. Evaluating additional liberalization policies would require a more sophisticated framework that incorporates

high. In general, if domestic producers have monopoly power and domestic and foreign goods are imperfect substitutes, then there is a terms-of-trade externality that the planner takes into account when setting optimal policy [e.g., Corsetti and Pesenti (2001)]. The regime rankings obtained here should therefore be interpreted with caution. 
these other frictions. These include, for example, the limited access of some private firms to credit; the financial repression of Chinese households that may have led to excessive savings and contributed to external imbalances; and state controls over the banking sector. In addition, a full evaluation of the implications of Chinese policy reforms would require studying the dynamics associated with the policy change along the transition path to a new steady state. Future research along these lines should be both important and promising.

\section{REFERENCES}

Aviat, A. And N. Coeurdacier (2007): "The Geography of Trade in Goods and Asset Holdings," Journal of International Economics, 71, 22-51.

BASU, S. (1995): "Intermediate Goods and Business Cycles: Implications for Productivity and Welfare," American Economic Review, 85, 512-531.

Basu, S. And J. G. Fernald (1997): "Returns to Scale in U.S. Production: Estimates and Implications," Journal of Political Economy, 105, 249-283.

Benigno, P. (2004): "Optimal monetary policy in a currency area," Journal of International Economics, 63, 293-320.

Bianchi, J. (2011): "Overborrowing and Systemic Externalities in the Business Cycle," American Economic Review, 101, 3400-3426.

Blanchard, O. J. and J. Galí (2007): "Real Wage Rigidities and the New Keynesian Model," Journal of Money, Credit, and Banking, 39, 35-65.

Calvo, G., L. Leiderman, and C. Reinhart (1996): "Inflows of Capital to Developing Countries in the 1990s," Journal of Economic Perspectives, 10, 12-139.

Calvo, G. A. (1983): "Staggered Prices in a Utility-Maximizing Framework," Journal of Monetary Economics, 12, 383-398.

(1991): "The Perils of Sterilization," IMF Staff Papers, 38, 921-926.

Carneiro, D. D. And T. Wu (2010): "Sovereign Risk and Out-of-Equilibrium Exchange Rate Dynamics," Review of Development Economics, 14, 699-711.

Chari, V., P. J. Kehoe, And E. R. McGrattan (2000): "Sticky Price Models of the Business Cycle: Can the Contract Multiplier Solve the Persistence Problem?" Econometrica, 68, 1151-1180.

Chen, Q., M. Funke, And M. Paetz (2012): "Market and Non-market Monetary Policy Tools in A Calibrated DSGE Model for Mainland China," BOFIT Discussion Papers, Bank of Finland. 
Christiano, L., M. Eichenbaum, And C. Evans (2005): "Nominal Rigidities and the Dynamics Effects of a Shock to Monetary Policy," Journal of Political Economy, $113,1-45$.

Clarida, R., J. Galí, and M. Gertler (2002): "Optimal Monetary Policy in Open versus Closed Economies: An Integrated Approach," American Economic Review, 91, 248-252.

Coeurdacier, N. And H. Rey (2011): "Home Bias in Open Economy Financial Macroeconomics," NBER Working Paper 17691.

Cole, H. L. And M. OBstfeld (1991): "Commodity Trade and International Risk Sharing: How Much Do Financial Markets Matter?" Journal of Monetary Economics, 28, 3-24.

Corsetti, G., L. Dedola, And S. Leduc (forthcoming): "Optimal Monetary Policy in Open Economies," in Handbook of Monetary Economics, ed. by M. Woodford and B. Friedman, Elsevier.

Corsetti, G. And P. Pesenti (2001): "Welfare and Macroeconomic Interdependence," Quarterly Journal of Economics, 116(2), 421-445.

De PaOli, B. And A. Lipinska (2013): "Capital Controls: A Normative Analysis," Federal Reserve Bank of New York Satff Report no. 600.

Erceg, C. J., D. W. Henderson, And A. T. Levin (2000): "Optimal Monetary Policy with Staggered Wage and Price Contracts," Journal of Monetary Economics, 46, 218-313.

FArhi, E. And I. Werning (2012): "Dealing with the Trilemma: Optimal Capital Controls with Fixed Exchange Rates," NBER Working Paper 18199.

Feenstra, R. C., M. Obstfeld, And K. N. Russ (2012): "In Search of the Armington Elasticity," Unpublished manuscript, University of California Davis.

Forbes, K., M. Fratzscher, And R. Straub (2013): "Capital Controls and Macroprudential Measures: What Are They Good For?" DIW Berlin Working Paper 1343.

Gabaix, X. And M. Maggiori (2013): "International Liquidity and Exchange Rate Dynamics," Unpublished Manuscript New York University.

Galí, J. And T. Monacelli (2005): "Monetary Policy and Exchange Rate Volatility in a Small Open Economy," 72, 707-734.

Glick, R. And M. Hutchison (2009): "Navigating the Trilemma: Capital Flows and Monetary Policy in China," Journal of Asian Economics, 20, 205-224. 
HuAnG, K. X. And Z. LiU (2005): "Inflation Targeting: What Inflation Rate to Target?" Journal of Monetary Economics, 52, 1435-1462.

Jeanne, O. (2012): "Capital Account Policies and the Real Exchange Rate," PIIE Working Paper WP 12-14.

Jeanne, O. And A. KorineK (2010): "Managing Credit Booms and Busts: A Pigouvian Taxation Approach," NBER Working Paper 16377.

Kletzer, K. And M. M. Spiegel (1998): "Speculative Capital Inflows and Exchange Rate Targeting in the Pacific Basin," in Managing Capital Flows and Exchange Rates: Perspectives from the Pacific Basin, ed. by R. Glick, Cambridge University Press, chap. 13, 409-436.

LiU, Z. AND E. PAPPA (2008): "Gains from International Monetary Policy Coordination: Does It Pay to Be Different?" Journal of Economic Dynamics and Control, $32,2085-2117$.

Mankiw, N. G. And R. Reis (2003): "What Measure of Inflation Should a Central Bank Target?" Journal of European Economic Association, 1, 1058-1086.

Miao, J. And T. Peng (2011): "Business Cycles and Macroeconomic Policy in China: Evidence from an Estimated DSGE Model," Unpublished manuscript, Boston University.

Ostry, J. D., A. R. Ghosh, K. Habermeier, M. Chamon, M. S. Qureshi, And D. B. Reinhart (2010): "Capital Inflows: The Role of Controls," IMF Staff Position note SPN/10/04, February 19.

Pencavel, J. (1986): "Labor supply of men: A survey." in Handbook of Labor Economics, ed. by O. Ashenfelter and R. Layard, Amsterdam: Elsevier Science, 3-102.

Prasad, E., T. Rumbaugh, and Q. Wang (2005): "Putting the Cart Before the Horse?: Capital Account Liberalization and Exchange Rate Flexibility in China," IMF Policy Discussion Paper No. 05/1.

RotemberG, J. J. (1982): "Sticky Prices in the United States," Journal of Political Economy, 90, 1187-1211.

Song, Z., K. Storesletten, And F. Zilibotti (2013): "Growing (with Capital Controls) Like China," Unpublished manuscript, University of Chicago Booth School of Business, University of Oslo, and University of Zurich.

TAYlor, J. B. (1993): "Discretion versus Policy Rules in Practice," Amsterdam, vol. 39 of Carnegie-Rochester Conference Series on Public Policy, 195-214.

Woodford, M. (2003): Interest and Prices: Foundations of a Theory of Monetary Policy, Princeton, New Jersey: Princeton University Press. 
TABLE 1. Calibrated parameters

\begin{tabular}{|c|c|c|}
\hline Parameter & Description & value \\
\hline & Preferences & \\
\hline$\beta$ & Subjective discount factor & 0.995 \\
\hline$\Phi_{m}$ & Utility weight on money balances & 0.06 \\
\hline \multirow[t]{2}{*}{$\eta$} & Inverse Frisch elasticity & 2 \\
\hline & Technologies & \\
\hline$\phi$ & Cost share of intermediate goods & 0.50 \\
\hline \multirow[t]{2}{*}{$\bar{\lambda}_{z}$} & Mean productivity growth rate & 1.02 \\
\hline & Nominal rigidities & \\
\hline$\theta_{p}$ & Elasticity of substitution between differentiated goods & 10 \\
\hline \multirow[t]{2}{*}{$\Omega_{p}$} & Price adjustment cost & 60 \\
\hline & Portfolio adjustment & \\
\hline$\Omega_{b}$ & Portfolio adjustment cost parameter & 0.6 \\
\hline \multirow[t]{2}{*}{$\bar{\psi}$} & Average portfolio share of domestic bonds & 0.9 \\
\hline & International trade & \\
\hline$\alpha$ & Share of domestic intermediate goods & 0.7556 \\
\hline \multirow[t]{2}{*}{$\theta$} & Export demand elasticity & 1.5 \\
\hline & Shock processes & \\
\hline$\rho_{r}$ & Persistence of foreign interest rate shock & 0.98 \\
\hline$\rho_{x}$ & Persistence of export demand shock & 0.95 \\
\hline$\sigma_{r}$ & Standard deviation of foreign interest rate shock & 0.01 \\
\hline$\sigma_{x}$ & Standard deviation of export demand shock & 0.01 \\
\hline
\end{tabular}


TABLE 2. Macroeconomic stability and welfare under alternative policy regimes

\begin{tabular}{lllll}
\hline \hline & Benchmark & Open capital account & Flexible exchange rate & Full reform \\
\hline$\sigma_{y}$ & 0.0327 & 0.0289 & 0.0111 & 0.0101 \\
$\sigma_{\pi}$ & 0.0155 & 0.0136 & 0.0041 & 0.0036 \\
$\sigma_{L}$ & 0.0217 & 0.0193 & 0.0143 & 0.0141 \\
$\sigma_{q}$ & 0.1416 & 0.1269 & 0.1031 & 0.0979 \\
$\sigma_{c a}$ & 3.5080 & 3.3712 & 3.4261 & 3.3701 \\
Welfare gains & - & 0.0029 & 0.0077 & 0.0079 \\
\hline
\end{tabular}

Note: The terms $\sigma_{y}, \sigma_{\pi}, \sigma_{L}, \sigma_{q}$, and $\sigma_{c a}$ denote the standard deviations of real GDP, inflation, employment, the real exchange rate, and the current account. 
Share of Foreign Reserves in PBOC Assets Percent

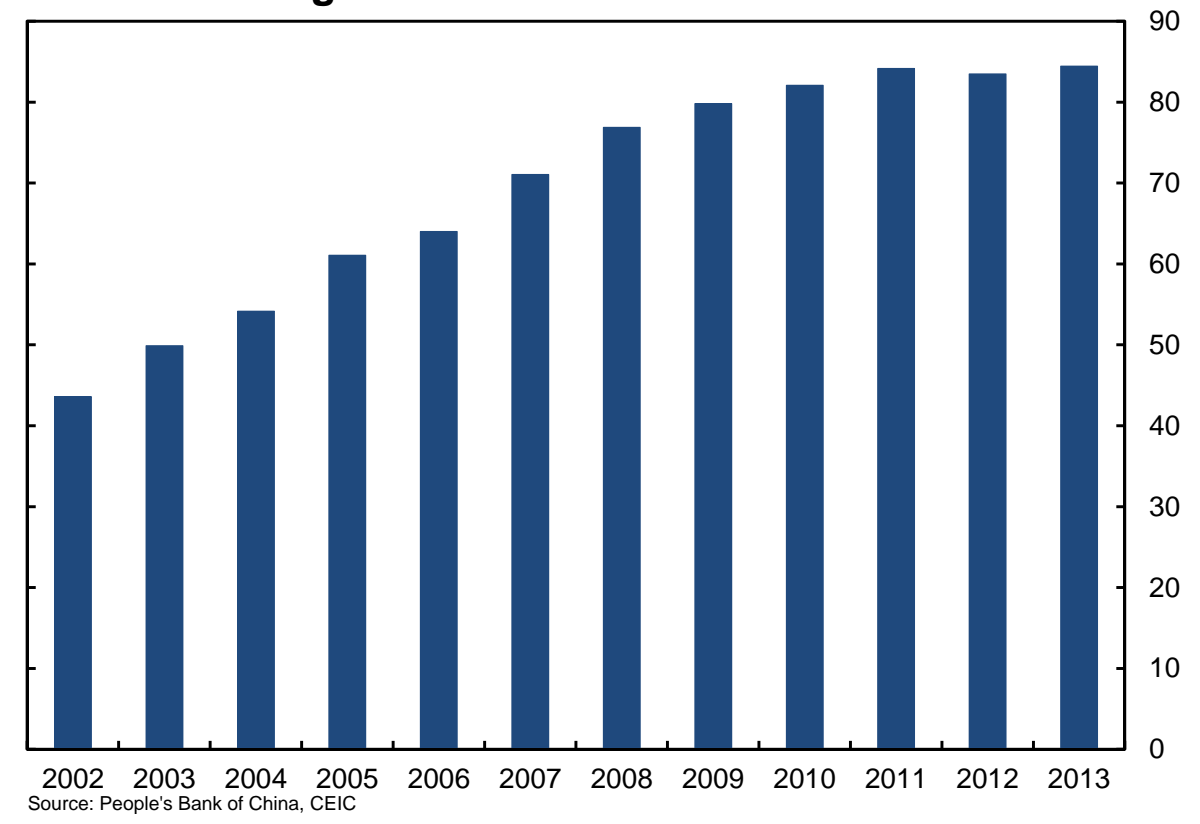

FiguRE 1. China's current account surpluses and foreign reserve accumulations 
Chinese Interbank Rate vs. US Treasury Rate

3 month maturities

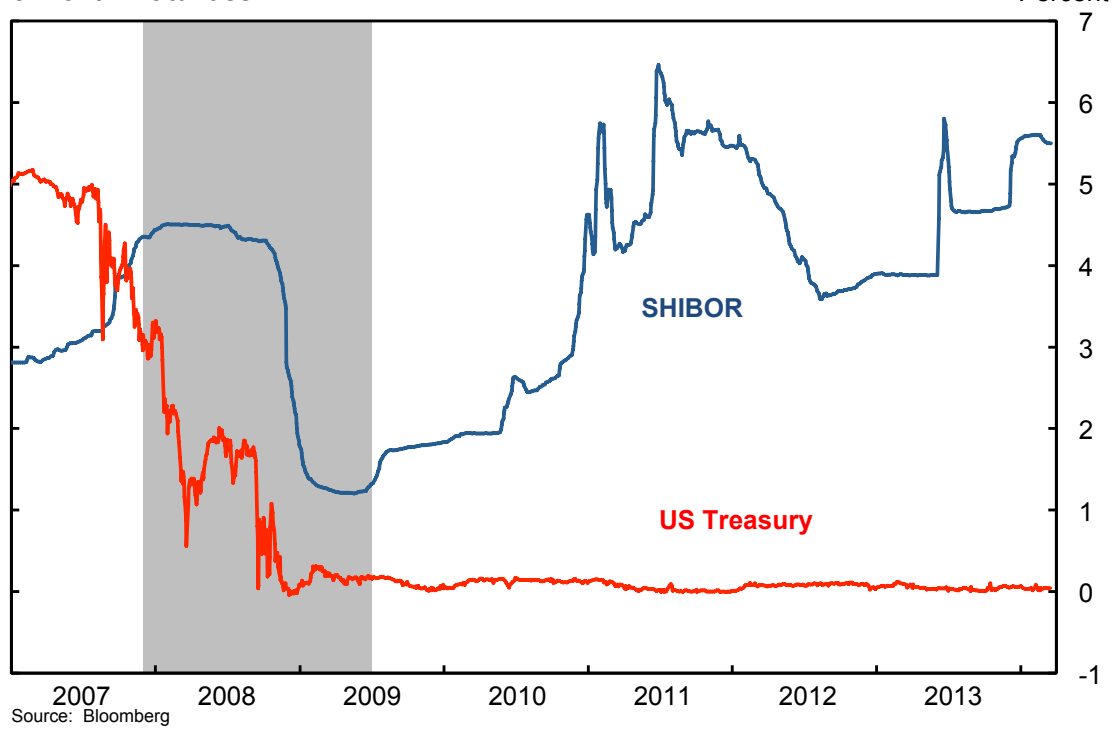

FiguRE 2. China SHIBOR (Shanghai Interbank Offered Rate) vs. U.S. three-month Treasury bills rate. The grey area indicates the Great Recession period in the United States. 


\section{China's Consumer Price Inflation}

Year-over-year change

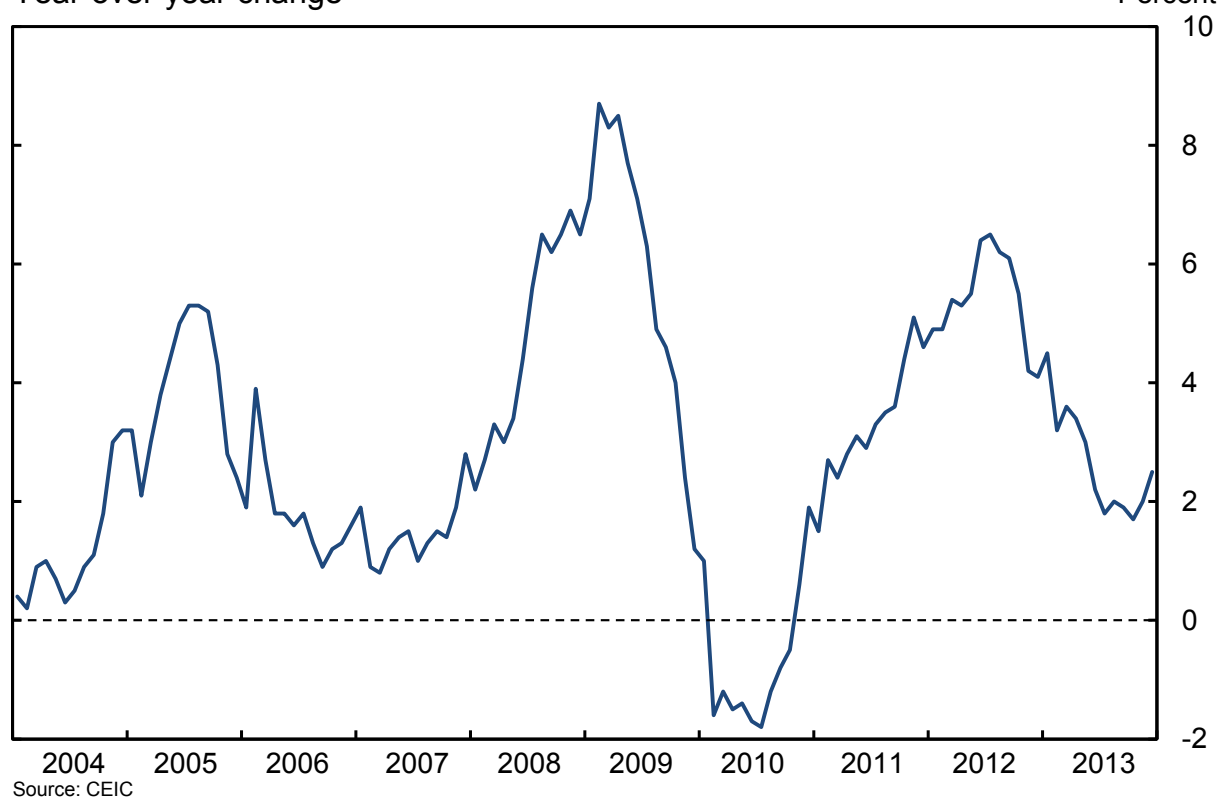

Figure 3. China's consumer price inflation 

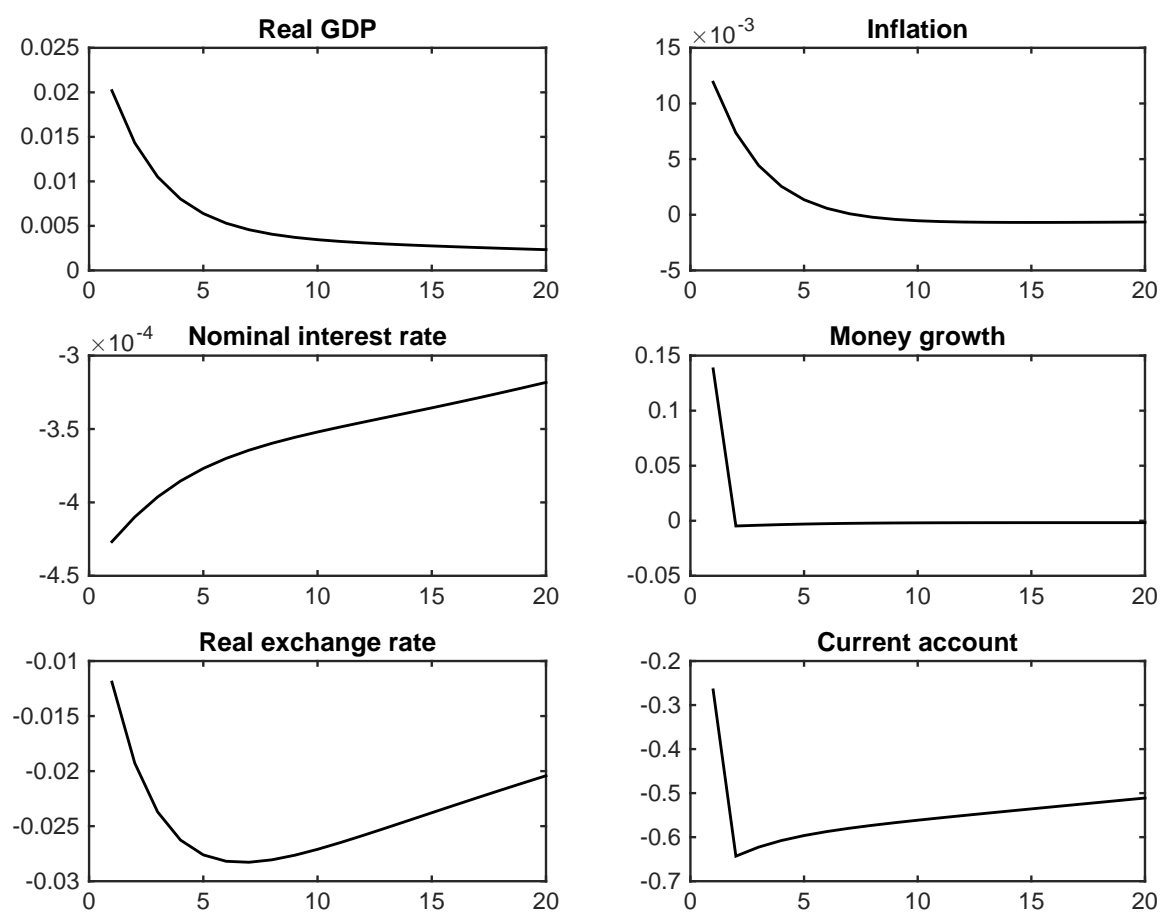

FiguRE 4. Impulse responses to a decline in the foreign interest rate in the benchmark model. 

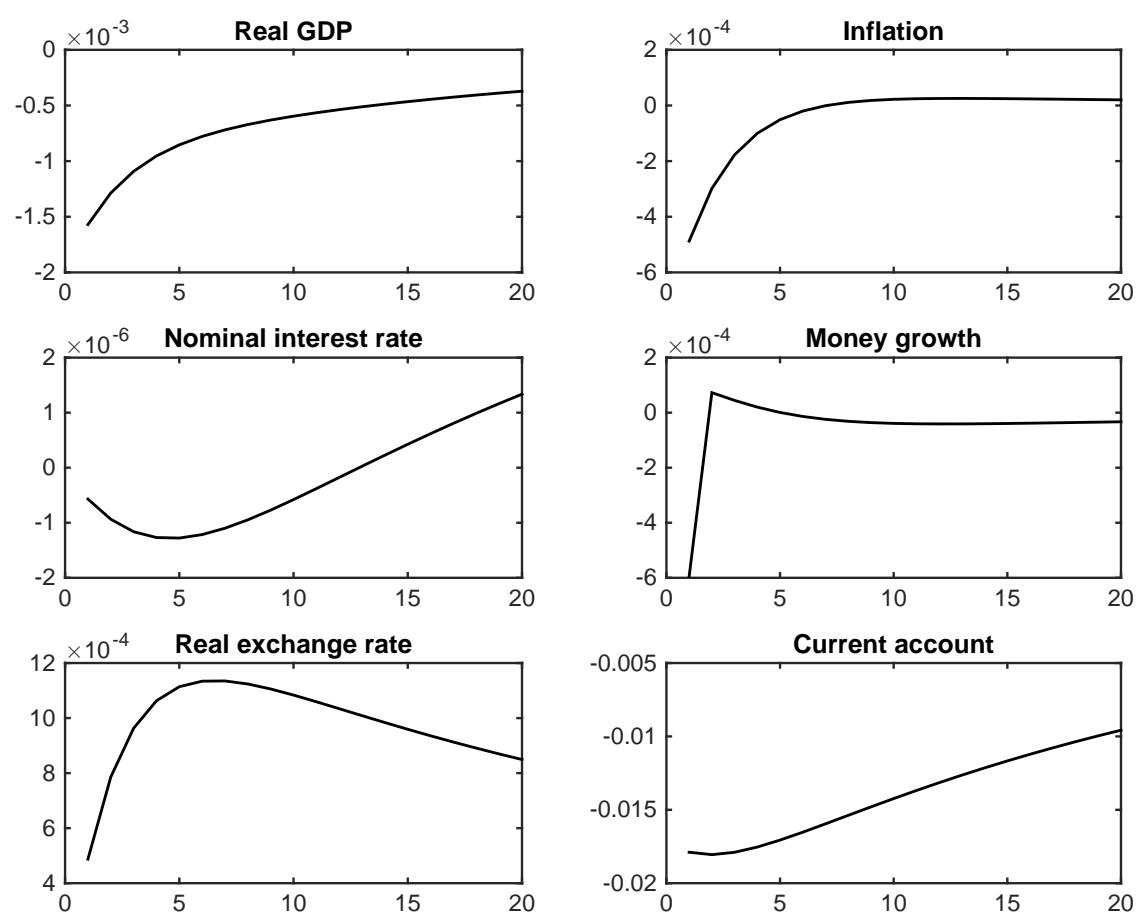

FiguRE 5. Impulse responses to a decline in export demand in the benchmark model. 